\title{
TUMOR NECROSIS FACTOR- $\alpha$, INTERLEUKIN 1, AND PHORBOL MYRISTATE ACETATE ARE INDEPENDENT ACTIVATORS OF NF-אB WHICH DIFFERENTIALLY ACTIVATE T CELLS
}

\author{
Stephanie W. Krasnow, ${ }^{1} \quad$ Liqian Zhang, ${ }^{1} \quad$ Kwanyee Leung, \\ Laurelee Osborn, ${ }^{1}$ Steven Kunkel, ${ }^{2}$ Gary J. Nabel ${ }^{1}$
}

\begin{abstract}
Gene expression in eukaryotic cells can be altered in different ways by extracellular agents, including mitogens and cytokines. Such differential gene expression is mediated in part through the effects of these stimuli on distinct sets of cellular transcription factors. In this report, the effects of phorbol myristate acetate, tumor necrosis factor- $\alpha$ (TNF- $\alpha$ ), and interleukin 1 (IL-1) on differential gene expression in the LBRM mouse T-lymphoma cell line are examined. Although these three different stimuli produce similar levels of induction of the NF-kB transcription factor, it is reported that they cause differential expression of other cellular activation genes, including c-fos and IL-2. The roles of IL-1 and TNF- $\alpha$ were also analyzed in EL-4 cells in the presence of a second activator, ionomycin. IL-1, but not TNF- $\alpha$, was found to stimulate the IL-2 enhancer in the presence of this costimulator. These findings suggest that one transcription factor can be the target of cellular activators that exert otherwise different effects on gene expression. Cellular activation pathways can therefore be defined by the set of transcription factors stimulated within a cell. This approach may allow a more precise definition of the requirements for differential gene activation in different cell types and thereby provide a basis for the selective manipulation of gene expression in cytokine-responsive cells.
\end{abstract}

Copyright $\odot 1991$ by W.B. Saunders Company

Cytokines, including tumor necrosis factor- $\alpha$ (TNF- $\alpha$ ) and interleukin 1 (IL-1), act on a variety of immune and nonimmune cells where they induce changes in cell proliferation and differentiation. These cytokines can alter gene expression by modulating transcription factors that regulate specific genes. Despite their divergent effects, some cytokines and mitogens have common functions. For example, TNF- $\alpha$, IL-1, and phorbol myristate acetate (PMA) all stimulate the DNA binding activity of NF- $-B^{1-3}{ }^{1-3} \mathrm{NF}-\mathrm{\kappa B}$ is a transcription factor that stimulates the human immunodeficiency virus (HIV) enhancer in activated $\mathrm{T}$ cells ${ }^{2}$

From the Howard Hughes Medical Institute, University of Michigan Medical Center, Departments of Internal Medicine and Biological Chemistry, Ann Arbor, $\mathrm{MI}^{1}$; and the Department of Pathology, University of Michigan Medical School, Ann Arbor, MI. ${ }^{2}$

Address reprint requests to: Gary J. Nabel, M.D., Ph.D., Howard Hughes Medical Institute, University of Michigan Medical Center, 1150 W. Medical Center Dr., MSRB I, Room 4510, Ann Arbor, MI 48109-0650.

Copyright $\odot 1991$ by W.B. Saunders Company

$1043-4666 / 91 / 0305-0019 \$ 5.00 / 0$

KEY WORDS: IL-1/NF-kB/phorbol esters/T-cell activation/ TNF- $\alpha$ and regulates several cellular gene products in different cell types including immunoglobulin light chain, IL-2 receptor alpha, beta interferon, serum amyloid $A$, histocompatibility antigens, and cytokines. ${ }^{4-15}$

Although the effects of these agents had been examined in different cell types, it was unknown whether these independent activators caused similar changes in gene expression in one cell. In this study, we have analyzed the mouse T-cell line LBRM $^{16}$ whose NF-кB binding activity can be activated comparably by PMA, TNF- $\alpha$, and IL-1. Our data suggest that these three agents, which activate NF- $\mathrm{kB}$ binding, act disparately within these cells, having different effects on c-fos and AP-1-dependent gene activation, as well as differentially regulating IL-2 secretion. These findings suggest that cytokines and mitogens that activate a common transcription factor can also stimulate distinct sets of transcription factors and activation genes in one T-cell type. Because these agents probably act through different second messengers, it is likely that convergent pathways result in the activation of common transcription factors, such as NF- $\mathrm{kB}$. By defining the unique and overlapping sets of transcriptional regulatory proteins activated by each agent, cellular activation pathways can be defined specifically, the mechanisms of gene 
activation can be further elucidated, and control of specific cellular genes can be achieved.

\section{RESULTS}

\section{$N F=\kappa B$ Binding Activity and Stimulation of the Human Immunodeficiency Virus Enhancer}

The mouse LBRM T-cell lymphoma synthesizes IL-2 in response to IL-1 ${ }^{16-18}$ Incubation of LBRM cells with IL-1 also induces NF- $\mathrm{KB}$ binding activity and stimulates the HIV enhancer through the $\mathrm{\kappa B}$ regulatory element.' We first examined whether PMA, TNF- $\alpha$, and IL-1 stimulated comparable NF- $\mathrm{kB}$ binding activity within LBRM cells. LBRM cells were incubated with PMA, TNF- $\alpha$, or IL-1, and an electrophoretic mobility shift assay was performed to determine NF- $\mathrm{kB}$ binding activity. ${ }^{2,12}$ All agents induced comparable $\mathrm{NF}-\kappa \mathrm{B}$ binding activity, and all inducible complexes were competed specifically by unlabeled $\kappa \mathrm{B}$ site, but not by an unrelated IL-2 fragment (Fig. 1A, lanes 1 through 12). The time course of stimulation with all three agents was similar, and NF- $\mathrm{KB}$ binding activity was maximal between 15 and $240 \mathrm{~min}$ after activation (data not shown). Another DNA binding protein that recognizes the immunoglobulin octamer motif ${ }^{1,20}$ showed no change in binding following stimulation with any of these stimulants (Fig. 1A, lanes 13 through 16).

To determine whether the binding activity induced by each agent correlated with transcriptional activation, the HIV enhancer linked to the chloramphenicol acetyltransferase (CAT) gene ${ }^{2}$ was transfected into LBRM cells. Twenty-four hours after transfection, cells were incubated for an additional $20 \mathrm{~h}$ in the presence of recombinant murine TNF- $\alpha$, recombinant murine IL-1, or PMA. CAT activity was comparably stimulated using $150 \mathrm{U} / \mathrm{mL}$ of TNF- $\alpha$ or $200 \mathrm{U} / \mathrm{mL}$ of IL-1 (Fig. 1B). Similar results have been obtained with plasmids containing multiple copies of $\kappa \mathrm{B}$ linked to a heterologous promoter, and mutations of the $\kappa B$ sites abolished this stimulation (data not shown) as in other PMA, TNF- $\alpha$, or IL-1 responsive cells. ${ }^{1}$

\section{Differential Activation of AP-1 Transcription}

$\mathrm{NF}-\mathrm{kB}$ is one of several transcription factors stimulated by PMA. Among the other known PMA-
Figure 1. NF-kB binding activity and function in $\mathbf{L B R M}$ cells.

(A) Analysis of PMA and cytokine inducible complexes in LBRM cells using the electrophoretic mobility shift assay. Nuclear extracts were prepared from cells treated as indicated and incubated with a radiolabeled $\kappa B$ probe (lanes 1 through 12) or an immunoglobulin octamer probe (lanes 13 through 16) alone or with the unlabeled competitors $(\kappa B)$ from the HIV enhancer or octamer from IL-2. ${ }^{12}$ Arrows denote specifically competed complexes. (B) 107 LBRM cells were transfected using DEAE-dextran with $20 \mu \mathrm{g}$ of HIV-CAT plasmid (O), AP-1-CAT plasmid (X), or a mutant AP-1-CAT (ם) plasmid altered in the AP-1 sites.
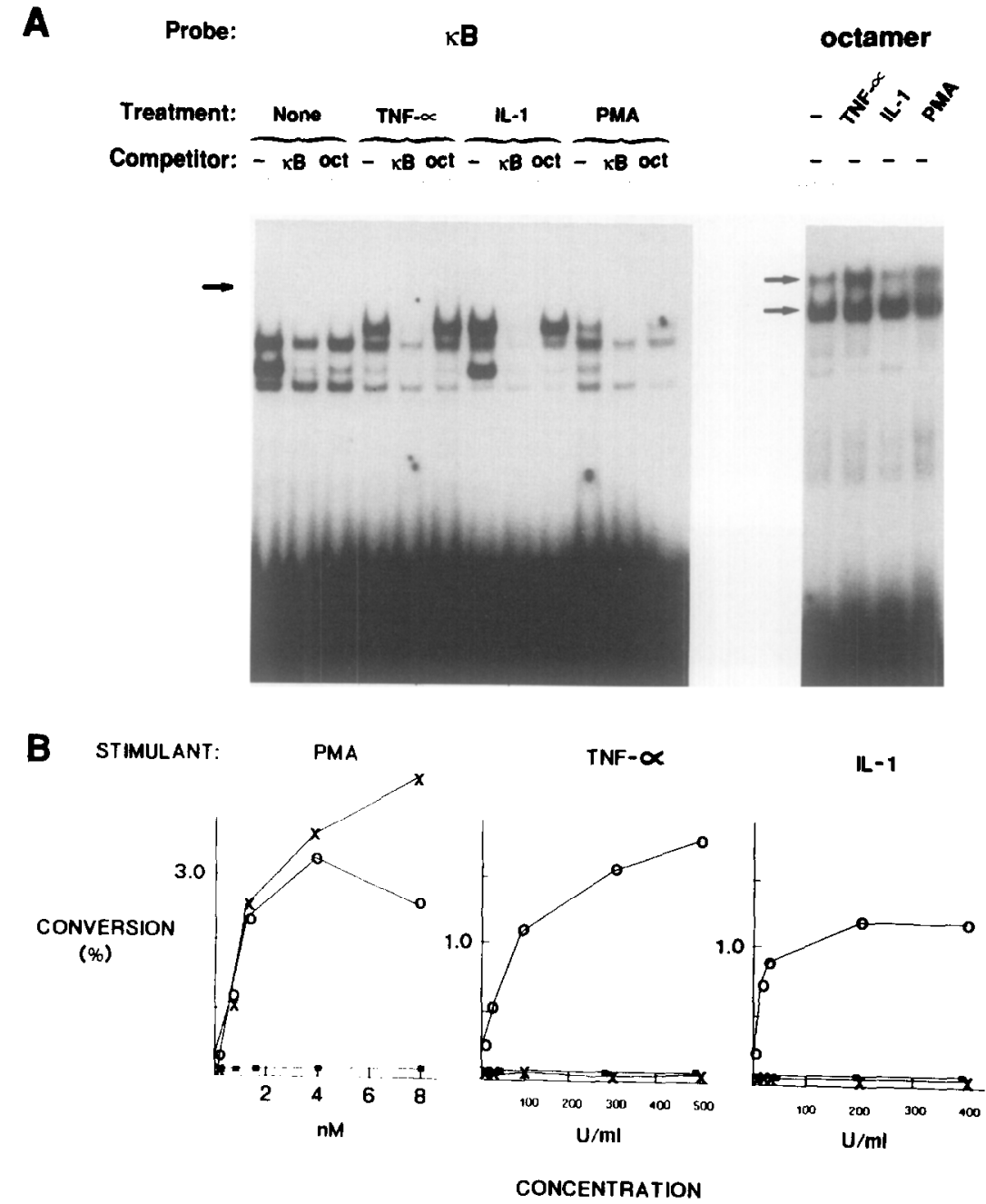
responsive elements is the AP-1 motif, ${ }^{21,22}$ which binds complexes of Jun and Fos transcription factors. We compared activation of $\kappa \mathrm{B}$ and AP-1 sites by PMA, TNF- $\alpha$, and IL- 1 . Because the mechanism that regulates AP-1 activation is controversial, ${ }^{21-25}$ we examined the ability of LBRM cells to functionally activate an AP-1 reporter plasmid. Although PMA stimulated the AP-1 enhancer element in LBRM cells, TNF- $\alpha$ and IL-1 had no detectable effect on this element at concentrations that activated NF- $\mathrm{kB}$ binding and the HIV enhancer (Fig. 1B). So despite their ability to stimulate NF- $\mathrm{kB}, \mathrm{TNF}-\alpha$ and IL-1 do not affect another PMA-responsive element, AP-1, in T cells.

To determine whether AP-1 activation was mediated by an increase in c-jun RNA, total RNA, prepared from LBRM cells stimulated with PMA, TNF- $\alpha$, or IL-1 for $1 \mathrm{~h}$, was evaluated by Northern blot analysis. At least two major RNA species, as described in other cells, ${ }^{25-28}$ hybridized to a c-jun probe; however, the steady-state levels of any of these mRNAs changed by less than twofold (Fig. 2A). In contrast, a 2.2-kilobase $(\mathrm{kb})$ RNA species that hybridized to a c-fos probe was induced by PMA but not by cytokines (Fig. 2B). Similar results were observed with RNA prepared after stimu-

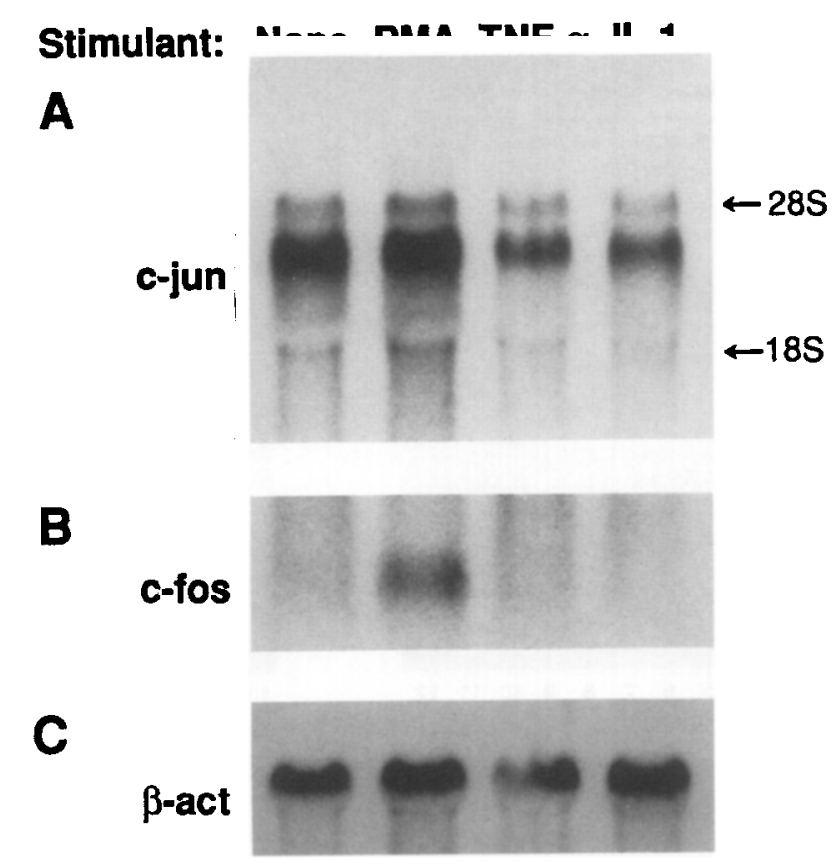

Figure 2. The effect of PMA and cytokines on c-jun and c-fos gene expression in LBRM cells.

$10^{7}$ LBRM cells were incubated for $1 \mathrm{~h}$ with $16 \mathrm{nM}$ PMA, $100 \mathrm{U} / \mathrm{mL}$ recombinant murine TNF- $\alpha$, or $10 \mathrm{U} / \mathrm{mL}$ recombinant murine IL-1. Total RNA $(20 \mu \mathrm{g})$ was isolated from these cells and transferred to Gene Screen Plus (Du Pont, NEN, Boston, MA). (A) Hybridization of Northern blot with a radiolabeled murine c-jun cDNA probe ${ }^{27}$ (B) A second Northern blot of the same preparations of total cellular RN $\Lambda$ as in $(\Lambda)$ hybridized with radiolabeled murine $c$ - $f o s .{ }^{69}(\mathrm{C})$ Northern blot shown above (A) was rehybridized with a radiolabeled $\beta$-actin probe. ${ }^{70}$ lation for $30 \mathrm{~min}$ (data not shown). Although other explanations are possible, this result is consistent with the notion that expression of the AP-1 reporter is regulated by the induction of c-fos, which subsequently interacts with a c-jun-like product that facilitates binding to the AP-1 site, perhaps through formation of a heterodimer. ${ }^{29-37}$

\section{Selective Activation of Interleukin 2 Secretion by Cytokines}

To compare the effects of TNF- $\alpha$, IL- 1 , and PMA on a different activation pathway, ${ }^{38}$ their effects on IL-2 secretion were analyzed. Supernatants from LBRM cells incubated with TNF- $\alpha$, IL-1, or PMA for $24 \mathrm{~h}$ were assayed for IL-2 activity. IL-1, similar to PMA, stimulated significant levels of IL-2 production (Fig. $3 \mathrm{~A})$. In contrast, TNF- $\alpha$ levels even as high as $\mathbf{1 , 0 0 0}$ $\mathrm{U} / \mathrm{mL}$ (data not shown), had no effect (Fig. 3A). Thus, although TNF- $\alpha$ and IL-1 are similar in their ability to stimulate NF- $\mathrm{kB}$ binding and activate the HIV enhancer, these two agents have markedly different effects on IL-2 production in LBRM cells. These results are also observed in the presence of a costimulant. In EL-4 cells, activation of the IL-2 enhancer was induced in the presence of ionomycin, a costimulant. As in LBRM cells, PMA or IL-1 stimulation caused marked enhancer activation, although TNF- $\alpha$ did not. This effect was mediated in part through $\mathrm{\kappa B}$ (Fig. $3 \mathrm{C}$ ). With a collagenase AP-1 reporter in these cells or in LBRM cells, II -1 does not stimulate CAT activity (Fig. 1) in contrast to its effect on the IL-2 AP-1 site ${ }^{39}$ (Fig. $3 \mathrm{~B}$ ), suggesting that Fos or Jun proteins differ in their ability to regulate the collagenase or IL-2 AP-1 sites.

Previous studies have shown that multiple gene products bind to $\mathrm{kB}$-like sequences, ${ }^{11,40-47}$ although it is not known whether all can activate transcription. Because it remained possible that PMA and cytokines could activate potentially distinct $\mathrm{kB}$ binding proteins, UV-crosslinking studies were performed. Several complexes were detected, including proteins of $\mathrm{M}_{\mathrm{r}} \sim 160$ $\mathrm{kDa}, \sim 90 \mathrm{kDa}$, and $\sim 50 \mathrm{kDa}$ (Fig. $4 \mathrm{a}, \mathrm{b}$, and c). (The precise size of the proteins may vary by up to $5 \mathrm{kDa}$ due to covalently bound DNA). However, no differences were noted between $\mathrm{\kappa B}$ binding proteins from cells stimulated with PMA, TNF- $\alpha$, or IL-1. These complexes were specific and not found in the presence of specific competitor or in unstimulated nuclear extracts (data not shown). The complex of $\sim 50 \mathrm{kDa}$ is consistent with previous reports of NF- $\mathrm{KB}^{11,45}$ and $\mathrm{KBF} 1{ }^{47} \mathrm{~A}$ $\kappa \mathrm{B}$ binding protein of $86 \mathrm{kDa}, \mathrm{HIVen} 86 \mathrm{~A}$, has also been identified by two-dimensional gel electrophoresis $^{44}$ and is consistent with the $\sim 90 \mathrm{kDa}$ protein. The $160 \mathrm{kDa}$ complex has not been previously described. 
A

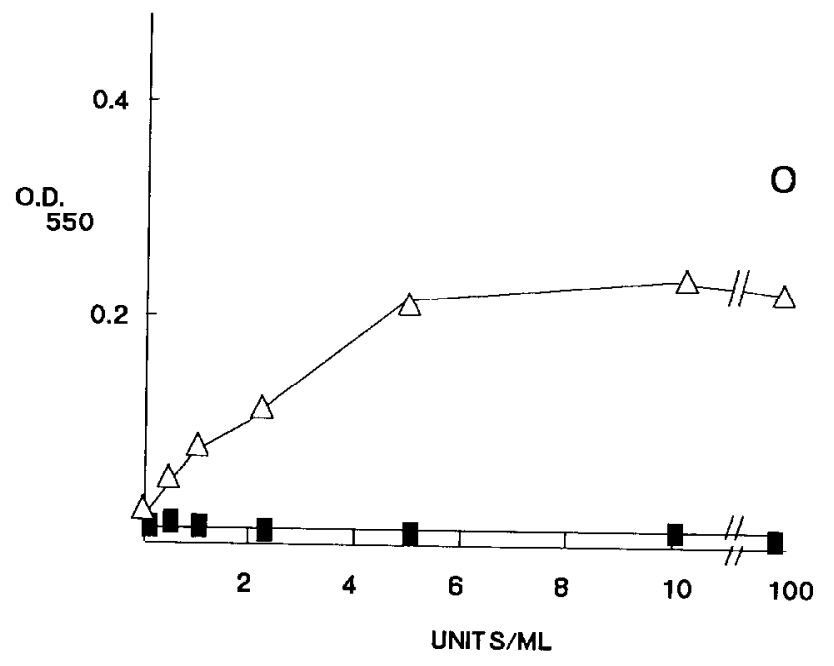

B

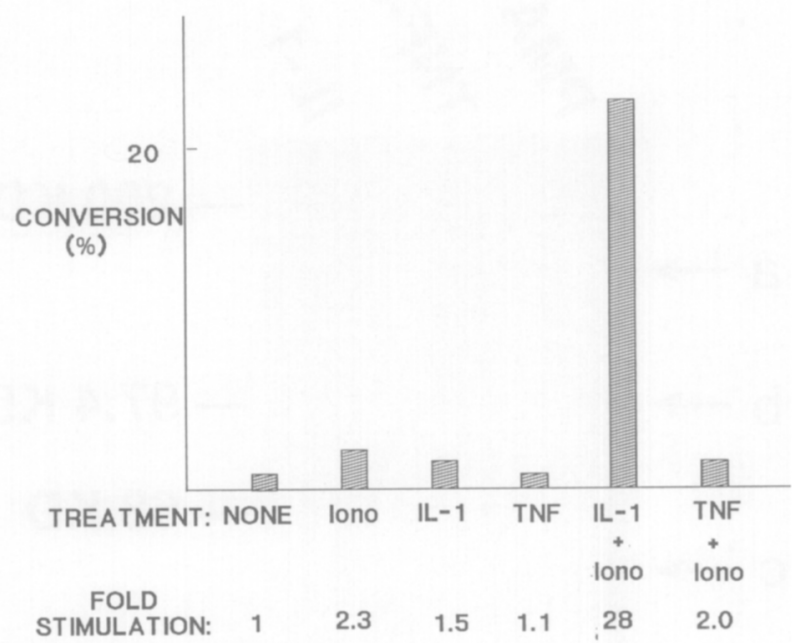

C

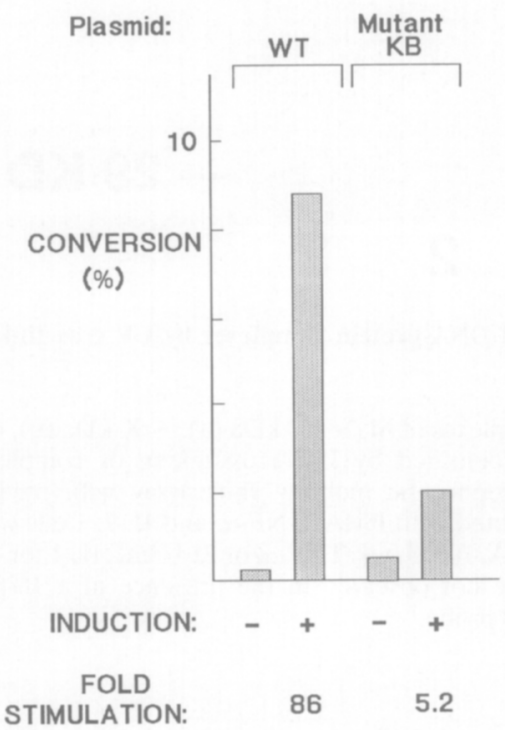

Figure 3. Cytokine and PMA induction of IL-2 secretion and the IL-2 enhancer in LBRM cells or EL-4 cells.

LBRM cells were incubated for $24 \mathrm{~h}$ in the presence of the indicated amounts of TNF- $\alpha(\boldsymbol{\square})$ or IL-1 $(\triangle)$. A single concentration of PMA (16 $\mathrm{nM}$ ) was included as a positive control (O). Secreted growth factor was measured using a colorimetric cell proliferation assay (A) and enhancer activity determined by CAT assay after transfection of EL-4 cells with the indicated stimuli (B). The wild type (WT) or mutant $\kappa B$ IL-2-CAT plasmids were transfected into EL-4 cells and CAT activity determined after incubation in media alone $(-)$ or in the presence of IL-1 and ionomycin $(+)(C)$.

\section{DISCUSSION}

PMA, TNF- $\alpha$, and IL-1 are alike in their ability to activate NF- $\mathrm{KB}$ binding and stimulate the HIV enhancer. In this study, we have used a target cell, LBRM, which is responsive to these agents and can be induced to secrete IL-2. Therefore, this cell line allows analysis of the relationship between cellular activators of NF- $\mathrm{KB}$ and those that stimulate IL-2 secretion. Our results suggest that different modes of NF-kB activation, e.g., TNF- $\alpha$ or IL-1 stimulation, differentially affect IL-2 secretion. A third inducer of NF- $\mathrm{BB}$ binding, PMA, acts differently from TNF- $\alpha$ or IL-1, stimulating IL-2 secretion and another PMA-responsive element, AP-1, which is not responsive to TNF- $\alpha$ or IL-1 in this cell line. Among its many effects, PMA is known to stimulate protein kinase $C^{48-50}$ Although controversial, ${ }^{, 1,52}$ there is no conclusive evidence that IL-1-induced gene expression is mediated by protein kinase $C^{53-58}$ With the exception of onc study using a different cell type ${ }^{59}$ it does not appear that TNF- $\alpha$ activates protein kinase $C^{56.58}$ Moreover, TNF- $\alpha$ stimulates NF- $\mathrm{kB}$ binding in cells unresponsive to PMA. ${ }^{1}$ It therefore appears that NF- $\mathrm{kB}$ is activated in association with different signal transduction pathways, some probably independent of protein kinase $C^{10,11,15}$

Although the mechanism is not fully defined, it is likely that multiple proteins regulate $\mathrm{NF}-\mathrm{kB}$ binding. For example, a cytoplasmic inhibitor of NF-kB, IkB, complexes to NF-kB and inhibits DNA binding activity. ${ }^{40,60}$ This complex can be dissociated by treatment with protein kinase $\mathrm{C}$ or with cyclic AMP-responsive protein kinases in vitro, facilitating dissociation and translocation of NF- $\mathrm{kB}$ to the nucleus. ${ }^{57}$ Binding of $\mathrm{I}_{\kappa} \mathrm{B}$ to $\mathrm{NF}-\mathrm{\kappa B}$ can also be inactivated in vitro by incubation with multiple protein kinases.$^{61}$ Thus, it is possible that TNF- $\alpha$ and IL-1 affect different steps in this pathway, 


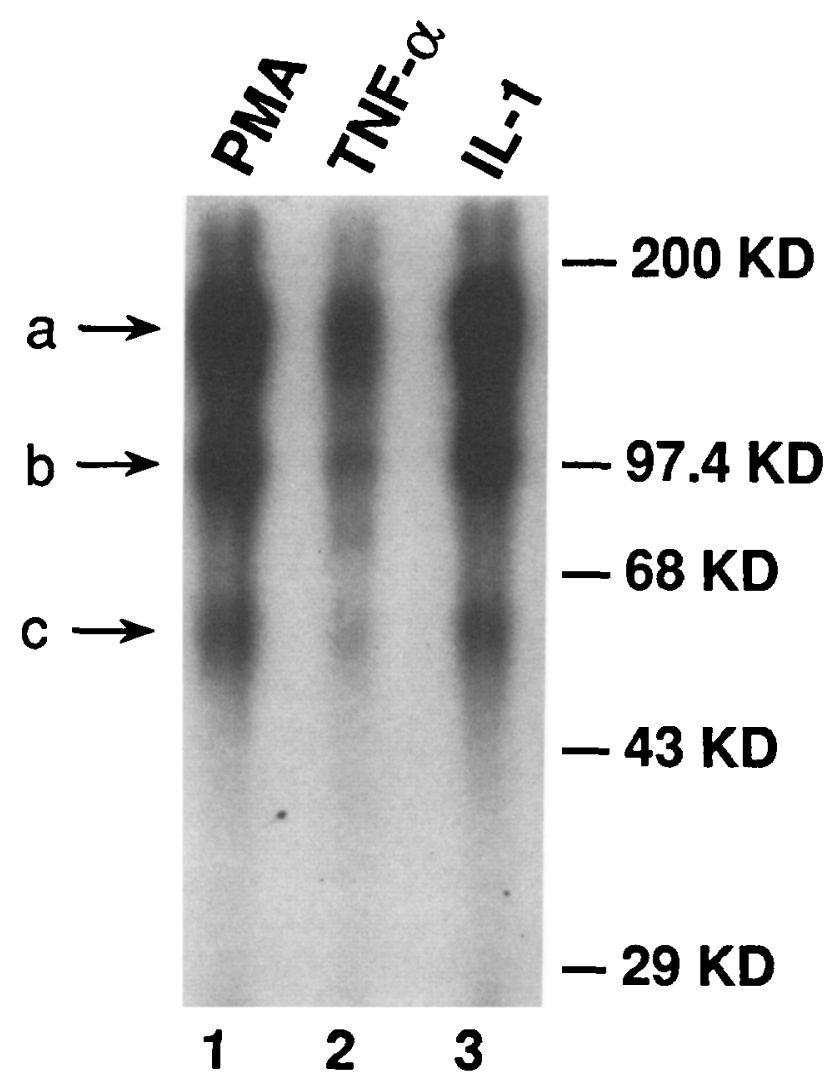

Figure 4. Analysis of DNA-protein complexes by UV crosslinking and SDS-PAGE.

Specific inducible complexes of $\mathrm{M}_{\mathrm{r}} \sim 160 \mathrm{kDa}$ (a), $\sim 90 \mathrm{kDa}$ (b), and $\sim 50 \mathrm{kDa}$ (c) were identified by UV crosslinking of complexes detected in an electrophoretic mobility shift assay with nuclear extracts from cells treated with PMA, TNF- $\alpha$, and IL-1. Cells were treated with $8 \mathrm{nM}$ PMA, $100 \mathrm{U} / \mathrm{mL}$ TNF- $\alpha$, or $25 \mathrm{U} / \mathrm{mL}$ IL- 1 for $4 \mathrm{~h}$. These complexcs werc not observed in the presence of a 10 -fold excess of unlabeled $\kappa \mathrm{B}$ probe.

including activation of different protein kinases, dissociation from the inhibitor, transport to the nucleus, or binding to DNA. Although it is possible that different $\mathrm{KB}$ binding proteins $\mathrm{s}^{12,15,41,42,46}$ could be stimulated by different activators, no differences in binding complexes were detected in this study using UV crosslinking. Furthermore, NF-kB complexes induced by all agents showed similar patterns of competition, suggesting that NF- $\mathrm{kB}$ is a set of transcription factors common to several activation pathways.

These studies also address the role of $\kappa \mathrm{B}$ binding proteins in the IL-2 enhancer. Previous studies have implicated a $\kappa B-l i k e$ site in the stimulation of the IL-2 enhancer. ${ }^{62}$ Using point mutations in this site, we also found a modest contribution of the $\mathrm{\kappa B}$ site in the IL-2 enhancer in EL4 cells (Fig. 3C). Similarly, this site was not required for induction by PMA, suggesting alternative responsive elements in this cell line. Previous studies have implicated activation of Fos and Jun in such ' $\mathrm{T}$ cells. ${ }^{39}$ Our findings also suggest that fos induction can be stimulated by PMA, although Jun was detected without deliberate activation, perhaps due to differences in basal transcription induced by serum. This finding may explain why IL-2 can be induced by PMA alone in this cell line.

Although the precise mechanism by which these transcription factors become activated in T cells is not yet known, several different models can be postulated to explain our findings (Fig. 5). For example, it is possible that TNF- $\alpha$, IL-1, and PMA each stimulate separate signal transduction pathways which independently activate NF- $\mathrm{BB}$ in association with different activation genes (Fig. 5A). A second possibility is that alternative second messengers converge to activate gene products through common mechanisms (Fig. 5B). Yet another possibility is that the same transcription factor (NF-kB) can become activated through separate signal transduction pathways by different mechanisms, some of which are shared among activators (Fig. 5C). Considerable complexity would be generated by the first model, and because activation genes such as IL-2 are induced by both IL-1 and PMA, we would suggest that one of the latter models is relevant to our findings. Because we have shown previously that TNF- $\alpha$ can induce NF- $\mathrm{kB}$ binding in cells unresponsive to PMA, ${ }^{1}$ our data would support the third model, whereby second messenger pathways converge on common transcription factors by shared and unique mechanisms.

Although we cannot yet define the precise mechanism, this study suggests that a major determinant of gene activation in different cell types is the substrate of each second messenger pathway. Because distinct cellular activators stimulate some transcription factors in common, the ability to understand the molecular basis of their activation and to delineate this network of interactions will help to achieve selective gene expression using cytokines. This approach may also help to clarify confusion regarding disparate effects of cytokines in different cell types. For example, TNF- $\alpha$ increases c-jun and c-fos expression in fibroblasts ${ }^{59}$ but has little effect on T cells (Fig. 2B). Taken together, the definition of the transcription factors stimulated by various extracellular agents provides a first step in the analysis of these signal transduction pathways. Further studies of the activation of these transcription factors will allow these common and unique pathways to be fully defined. In addition, because NF- $\kappa \mathrm{B}$ induction is associated with increases in HIV transcription, ${ }^{2,63-65}$ these findings also suggest potential strategies to decrease HIV gene expression while minimizing effects on other T-cell activation genes that mediate immunologic function. 

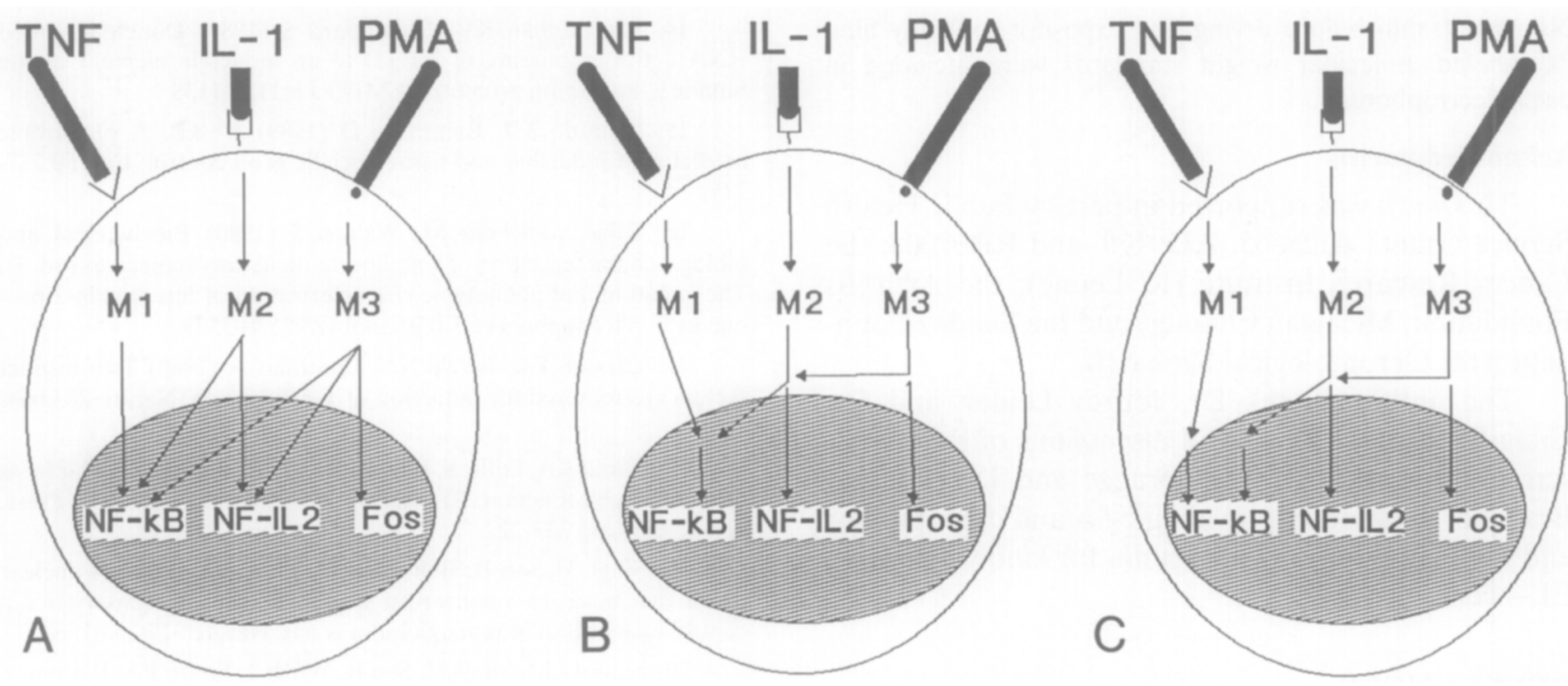

Figure 5. Alternative models of cellular activation.

Schematic representation of potential activation pathways that might lead to activation of NF-KB through (A) independent, (B) totally convergent, or (C) partially convergent mechanisms. M1, M2, and M3 indicate putative second messengers for TNF- $\alpha$, IL-1, and PMA, respectively. NF-IL-2 refers to the set of transcription factors, other than Fos or NF-kB, which lead to IL-2 secretion.

\section{MATERIALS AND METHODS}

\section{Cells and Nuclear Extracts}

Nuclear extracts were prepared from cells incubated for $2 \mathrm{~h}$ at $37^{\circ} \mathrm{C}$ in medium alone, $500 \mathrm{U} / \mathrm{mL}$ recombinant $\mathrm{TNF}-\alpha$ (Genzyme, Boston, MA), $100 \mathrm{U} / \mathrm{mL}(15 \mathrm{ng} / \mathrm{mL})$ recombinant IL-1 (Genzyme), or in 16 nM PMA (Sigma, St. Louis, $\mathrm{MO})$ as indicated. $10 \mu \mathrm{g}$ of nuclear extract, prepared as previously described, ${ }^{1}$ was used in the presence of $1 \mu \mathrm{g} \mathrm{dIdC}$. EL4-6.1 cells were kindly provided by Dr. Christopher D. Benjamin (Biogen).

\section{Plasmids}

The AP-1-CAT plasmid was prepared by inserting an oligonucleotide consisting of four tandem copies of the AP-1 sequence from the collagen I gene, ATGAGTCAG, into the $S a c I$ and $S m a I$ sites of an SV-40 promoter expression vector pSP-CAT. ${ }^{12}$ The AP-1-CAT mutant plasmid was prepared identically; the mutated sequence inserted in four copies was ATGATCACG. The IL-2-CAT plasmid was used as described ${ }^{66}$ or the ${ } \mathrm{B}$ mutant by modification of positions -205 to -195 to TTCTAGATCGA by site-specific mutagenesis. ${ }^{2}$

\section{Transfections and Chloramphenicol Acetyltransferase Assays}

Cells were transfected using DEAE-dextran as previously described. ${ }^{12}$ Twenty-four hours after transfection, cells were incubated for an additional $20 \mathrm{~h}$ in the presence of the indicated amounts of PMA, recombinant murine TNF- $\alpha$, or recombinant murine IL-1. In Fig. 3, ionomycin (1 $\mu \mathrm{M}), 25$ $\mathrm{U} / \mathrm{mL}$ recombinant human IL- $1 \alpha$ (Genzyme), and $200 \mathrm{U} / \mathrm{mL}$ of mouse recombinant TNF- $\alpha$ (Genzyme) were used as indicated. Cell extracts were prepared $44 \mathrm{~h}$ after transfection, transfection efficiencies normalized, and conversion of chloramphenicol to its acetylated forms assayed by standard methods. ${ }^{2,67}$ Results are representative of at least three independent transfections, and standard deviation for cach CAT determination was $\leq 10 \%$. Percent conversion of $\left[{ }^{14} \mathrm{C}\right]$ chloramphenicol to its acetylated forms is indicated.

\section{Cell Proliferation Assays}

Quantitation of secreted growth factor was performed by using an HT-2 cell indicator cell line, which was not responsive to IL-1 or IL-4, and a colorimetric assay was used to determine proliferation. ${ }^{68}$ Standard deviations were $<25 \%$ for each data point.

\section{UV Crosslinking and SDS-PAGE Analyses}

Radiolabeled probe for the $\kappa \mathrm{B}$ site was prepared by incubation of the 25 base long sense strand of single copy $\mathrm{kB}$ site with a complementary 10-base primer, $25 \mu \mathrm{M}$ dATP, dGTP, 5-bromo-dUTP and $10 \mu \mathrm{Ci}{ }^{32} \mathrm{P}-\alpha$-dCTP in the presence of the Klenow fragment of Escherichia coli DNA polymerase for $30 \mathrm{~min}$ at room temperature. At the completion of electrophoresis of the mobility shift gel, the polyacrylamide gel was exposed to UV light $(305 \mathrm{~nm})$ generated from an inverted UV light source at a distance of $5 \mathrm{~cm}$ from the light source for $60 \mathrm{~min}$ on ice. The gel was then exposed to Kodak X-Omat AR film (Rochester, NY) with an intensifying screen at $4^{\circ} \mathrm{C}$ overnight. Gel slices containing specific DNA-protein complexes were excised, soaked in $0.1 \%$ SDS for $10 \mathrm{~min}$ at room temperature, and transferred to a $7 \%$ SDS-polyacrylamide gel. After electrophoresis, gels were incubated with Autofluor (National Diagnostics, Manville, 
$\mathrm{NJ}$ ) for $60 \mathrm{~min}$ before drying and exposure to X-ray film. ${ }^{14} \mathrm{C}$-labeled molecular weight standards were included in each electrophoresis.

\section{Acknowledgments}

This work was supported in part by Public Health Service Grants AI26865, AI29179, and RR07008; the Cancer Research Institute (K. Leung); the Arthritis Foundation, Michigan Chapter; and the Sandoz Foundation for Gerontological Research.

The authors thank Dr. Jeffrey Leiden and Dr. Craig Thompson for helpful discussions of the manuscript; Dr. Benoit de Crombrugge and Dr. Rodrigo Bravo for generously providing c-fos and c-jun probes; and Dr. Christopher D. Benjamin for kindly providing EL-4 cells

\section{REFERENCES}

1. Osborn L, Kunkel S, Nabel GJ (1989) Tumor necrosis factor $\alpha$ and interleukin 1 stimulate the human immunodeficiency virus enhancer by activation of the nuclear factor $\mathbf{k B}$. Proc Natl Acad Sci USA 86:2336-2340.

2. Nabel G, Baltimore D (1987) An inducible transcription factor activates human immunodeficiency virus expression in $T$ cells. Nature 326:711-713.

3. Sen R, Baltimore D (1986) Inducibility of kappa immunoglobulin enhancer-binding protein NF- $\mathrm{kB}$ by a posttranslational mechanism. Cell 47:921-928.

4. Blanar MA, Burkly LC, Flavell RA (1989) NF-kappa B binds within a region required for B-cell-specific expression of major histocompatibility complex class II gene $\mathrm{E}$ alpha d. Mol Cell Biol 9:844-846.

5. Böhnlein E, Lowenthal JW, Siekevitz M, Ballard DW, Franza BR, Greene WC (1988) The same inducible nuclear protein(s) regulates mitogen activation of both the interleukin-2 receptoralpha gene and type 1 HIV. Cell 53:827-836.

6. Cross SL, Halden NF, Lenardo MJ, Leonard WJ (1989) Functionally distinct NF- $\mathrm{kB}$ binding sites in the immunoglobulin $\mathrm{\kappa}$ and IL-2 receptor $\alpha$ chain genes. Science 244:466-469.

7. Edbrooke MR, Burt DW, Cheshire JK, Woo P (1989) Identification of cis-acting sequences responsible for phorbol ester induction of human serum amyloid A gene expression via a nuclear factor $\mathrm{kb}$-like transcription factor. Mol Cell Biol 9:1908-1916.

8. Hoyos B, Ballard DW, Bohnlein E, Siekevitz M, Greene WC (1989) Kappa-B-specific DNA binding proteins: Role in the regulation of human interleukin-2 gene expression. Science 244:457-460.

9. Israel $\Lambda$, Kimura $\Lambda$, Kieran M, Yano O, Kanellopoulos, J, LeBail O, Kourilsky P (1987) A common positive transacting factor binds to enhancer sequences in the promoters of mouse $\mathrm{H}-2$ and $\beta-2$ microglobulin genes. Proc Natl Acad Sci USA 84:2653-2657.

10. Lenardo MJ, Fan C, Maniatis T, Baltimore D (1989) The involvement of $\mathrm{NF}-\mathrm{kB}$ in $\beta$-interferon gene regulation reveals its role as widely inducible mediator of signal transduction. Cell 57:287-294.

11. Lenardo MJ, Kuang A, Gifford A, Baltimore D (1988) NF- $\mathrm{kB}$ protein purification from bovine spleen: Nucleotide stimulation and binding site specificity. Proc Natl Acad Sci USA 85:88258829 .

12. Leung K, Nabel G (1988) HTLV-1 transactivator induces interleukin-2 receptor expression through an NF-кB-like factor. Nature 333:776-778.

13. Ruben S, Poteat H, Tan TH, Kawakami K, Roeder R, Haseltine W, Rosen CA (1988) Cellular transcription factors and regulation of IL-2 receptor gene expression by HTLV-1 tax gene product. Science 241:89-92.
14. Visvanathan KV, Goodbourn S (1989) Double-stranded RNA activates binding of NF- $\mathrm{KB}$ to an inducible element in the human $\beta$-interferon promoter. EMBO J 8:1129-1138.

15. Lenardo MJ, Baltimore D (1989) NF-kB: A pleiotropic mediator of inducible and tissue-specific gene control. Cell 58:227229.

16. Gillis S, Scheid M, Watson J (1980) Binchemical and biologic characterization of lymphocyte regulatory molecules (ed. 3). The isolation and phenotypic characterization of interleukin-2 producing $\mathrm{T}$ cell lymphomas. J Immunol 125:2570-2578.

17. Larsson EL, Iscove NN, Coutinho A (1980) Two distinct factors are required for induction of T-cell growth. Nature 283:664666.

18. Smith KA, Gillis S, Baker PE (1979) In the molecular basis of immune cell function. Elsevier/North Holland Biomedical Press, Amsterdam, pp 223-227.

19. Singh H, Sen R, Baltimore D, Sharp PA (1986) A nuclear factor that binds to a conserved sequence motif in transcriptional control elements of immunoglobulin genes. Nature 319:154-158.

20. Staudt LM, Singh H, Sen R, Wirth T, Sharp PA, Baltimore $D$ (1986) A lymphoid-specific protein binding to the octamer motif of immunoglobulin genes. Nature 323:640-643.

21. Angel P, Hattori K, Smeal T, Karin M (1988) The jun proto-oncogene is positively autoregulated by its product, Jun/AP-1. Cell 55:875-885.

22. Lee W, Mitchell PJ, Tjian RT (1987) Purified transcription factor AP-1 interacts with TPA-inducible enhancer elements. Cell 49:741-752.

23. Angel $P$, Imagawa $M$, Chiu $R$, Stein $B$, Imbra RJ, Rahmsdorf HJ, Jonat C, Herrlich P, Karin M (1987) Phorbol ester-inducible genes contain a common cis element recognized by a TPAmodulated trans-acting factor. Cell 49:729-739.

24. Chiu R, Boyle WJ, Meek J, Smeal T, Hunter T, Karin M (1988) The c-Fos protein interacts with c-Jun/AP-1 to stimulate transcription of AP-1 responsive genes. Cell 54:541-552.

25. Ryseck RP, Hirai SI, Yaniv M, Bravo R (1988) Transcriptional activation of c-jun during the $\mathrm{G}_{0} / \mathrm{G}_{1}$ transition in mouse fibroblasts. Nature 334:535-537

26. Ryder K, Lanahan A, Perez-Albuerne E, Nathans D (1989) Jun-D: A third member of the Jun gene family. Proc Natl Acad Sci USA 86:1500-1503.

27. Ryder K, Lau LF, Nathans D (1988) A gene activated by growth factors is related to the oncogene v-jun. Proc Natl Acad Sci USA 85:1487-1491.

28. Ryder K, Nathans D (1988) Induction of protooncogene c-jun by serum growth factors. Proc Natl Acad Sci USA 85:84648467.

29. Kouzarides T, Ziff E (1988) The role of the leucine zipper in the fos-jun interaction. Nature 336:646-651.

30. Halazonetis TD, Georgopoulos K, Greenberg ME, Leder P (1988) c-Jun dimerizes with itself and with c-Fos forming complexes of different DNA binding affinities. Cell 55:917-924.

31. Sassone-Corsi P, Ransone LJ, Lamph WW, Verma IM (1988) Dircet interaction between fos and jun nuclear oncoproteins: Role of the 'leucine zipper' domain. Nature 336:692-695.

32. Rauscher FJ III, Voulalas PJ, Franza BR Ir, Curran T (1988) Fos and Jun bind cooperatively to the AP-1 site: Reconstitution in vitro. Genes Dev 2:1687-1699.

33. Nakabeppu Y, Ryder K, Nathans D (1988) DNA binding activities of three murine Jun proteins: Stimulation by Fos. Cell 55:907-915.

34. Turner R, Tjian R (1989) Leucine repeats and an adjacent DNA binding domain mediate the formation of functional cFos-cJun heterodimers. Science 243:1689-1694.

35. Gentz R, Rauscher FJ III, Abate C, Curran T (1989) 
Parallel association of Fos and Jun leucine zippers juxtaposes DNA binding domains. Science 243:1695-1699.

36. Schuermann $M$, Neuberg M, Hunter JB, Jenuwein $T$, Ryseck RP, Bravo R, Muller R (1989) The leucine repeat motif in Fos protein mediates complex formation with Jun/AP-1 and is required for transformation. Cell 56:507-516.

37. Ransone LJ, Visvader J, Sassone-Corsi P, Verma IM (1989) Fos-Jun interaction: Mutational analysis of the leucine zipper domain of both proteins. Genes Dev 3:770-781.

38. Crabtree GR (1989) Contingent genetic regulatory events in T lymphocyte activation. Science 243:355-361.

39. Muegge K, Williams TM, Kant J, Karin M, Chiu R, Schmidt A, Siebenlist U, Young HA, Durum SK (1989) Interleukin-1 Costimulatory activity on the interleukin-2 promoter via Ap1. Science 246:249-251.

40. Baeuerle PA, Baltimore D (1988) Activation of DNAbinding activity in an apparently cytoplasmic precursor of the NF- $\mathrm{kB}$ transcription factor. Cell 53:211-217.

41. Baldwin AS, Sharp PA (1987) Binding of a nuclear factor to a regulatory sequence in the promoter of the mouse $\mathbf{H}-2 \mathrm{~K}^{\mathrm{b}}$ class $\mathbf{I}$ major histocompatibility gene. Mol Cell Biol 7:305-313.

42. Baldwin AS, Sharp PA (1988) Two transcription factors, $\mathrm{NF}-\mathrm{KB}$ and H2TF1, interact with a single regulatory sequence in the class I major histocompatibility complex promoter. Proc Natl Acad Sci USA 85:723-727.

43. Ballard DW, Bohnlein E, Lowenthal JW, Wano Y, Franza BR, Greene WC (1988) HTLV-I tax induces cellular proteins that activate the $\kappa B$ element in the IL-2 receptor $\alpha$ gene. Science 241:1652-1655.

44. Franza BR Jr, Josephs SF, Gilman MZ, Ryan W, Clarkson B (1987) Characterization of cellular proteins recognizing the HIV enhancer using microscale DNA-affinity precipitation assay. Nature 330:391-395.

45. Kawakami K, Scheidereit C, Roeder RG (1988) Identification and purification of human immunoglobulin-enhancer-binding protein (NF-kB) that activates transcription from a human immunodeficiency virus type 1 promoter in vitro. Proc Natl Acad Sci USA 85:4700-4704.

46. Singh H, LeBowitz JH, Baldwin AS Jr, Sharp PA (1988) Molecular cloning of an enhancer binding protein: Isolation by screening of an expression library with a recognition site DNA. Cell $52: 415-423$

47. Yano O, Kanellopoulos J, Kieran M, LeBail O, Israel A, Kourilsky P (1987) Purification of KBF1, a common factor binding to both $\mathrm{H}-2$ and $\beta 2$-microglobulin enhancers. EMBO J 6:3317-3324.

48. Castagna M, Takai Y, Kaibuchi K, Sano K, Kikkawa U, Nishizuka Y (1982) Direct activation of calcium-activated phospholipid-dependent protein kinase by tumor promoting phorbol esters. J Biol Chem 257:7847-7851.

49. Nishizuka Y (1984) The role of protein kinase C in cell surface signal transduction and tumor promotion. Nature 308:693698.

50. Chiu R, Imagawa M, Imbra RJ, Bockoven JR, Karin M (1987) Multiple cis- and trans-acting elements mediate the transcriptional response to phorbol esters. Nature 329:648-651.

51. Zlotnik A, Daine B (1986) Activation of Il 1-dependent and Il 1-independent $\mathrm{T}$ cell lines by calcium ionophore and phorbol ester. J Immunol 136:1033-1037.

52. Ostrowski J, Meier KE, Stanton TH, Smith LL, Bomsztyk $\mathrm{K}$ (1988) Interferon- $\gamma$ and interleukin- $1 \alpha$ induce transient translocation of protein kinase $\mathrm{C}$ activity to membranes in a $\mathrm{B}$ lymphoid cell line. J Biol Chem 263:13786-13790.
53. Avissar S, Stenzel KH, Novogrodsky A (1985) Selective effects of TPA and IL 1 on protein phosphorylation in murine thymocytes. Cell Immunol 96:462-471.

54. Abraham RT, Ho SN, Barna TJ, McKean DJ (1987) Transmembrane signaling during interleukin 1-dependent $\mathrm{T}$ cell activation. J Biol Chem 262:2719-2728.

55. Mukaida N, Kasahara T, Yagisawa H, Shioiri-Nakano K, Kawai $T$ (1987) Signal requirement for interleukin 1-dependent interleukin 2 production by a human leukemia-derived HSB.2 subclone. J Immunol 139:3321-3329.

56. Zhang YH, Lin JX, Yip YK, Vilcek J (1988) Enhancement of cAMP levels and of protein kinase $\mathrm{C}$ activity by tumor necrosis factor and interleukin 1 in human fibroblasts: Role in the induction of interleukin 6. Proc Natl Acad Sci USA 85:6802-6805.

57. Shirakawa F, Chedid M, Suttles J, Pollok BA, Mizel SB (1989) Interleukin 1 and cyclic AMP induce $\kappa$ immunoglobulin light-chain expression via activation of an NF- $\mathrm{kB}$-like DNA-binding protein. Mol Cell Biol 9:959-964.

58. Bird TA, Saklatvala J (1989) IL-1 and TNF transmodulate epidermal growth factor receptors by a protein kinase $\mathrm{C}$-independent mechanism. J Immunol 142:126-133.

59. Brenner DA, O'Hara M, Angel P, Chojkier M, Karin M (1989) Prolonged activation of $j u n$ and collagenase genes by tumour necrosis factor- $\alpha$. Nature 337:661-663.

60. Baeuerle PA, Baltimore D (1988) I kappa B: A specific inhibitor of the NF-kappa B transcription factor. Science 242:540546.

61. Ghosh S, Baltimore D (1990) Activation in vitro of NF- $\mathrm{kB}$ by phosphorylation of its inhibitor, IкB. Nature 344:678-682.

62. Hoyos B, Ballard PW, Bohnlein E, Siekewiz M, Greene WC (1989) Kappa-B-specific DNA binding proteins: Role in the regulation of human interleukin-2 gene expression. Science 244:457 460

63. Duh EJ, Maury WJ, Folks TM, Fauci AS, Rabson AB (1989) Tumor necrosis factor $\alpha$ activates human immunodeficiency virus type 1 through induction of nuclear factor binding to the NF- $\mathrm{KB}$ sites in the long terminal repeat. Proc Natl Acad Sci USA 86:59745978.

64. Folks TM, Clouse KA, Justement J, Rabson A, Duh E, Kehrl JH, Fauci AS (1989) Tumor necrosis factor $\alpha$ induces expression of human immunodeficiency virus in a chronically infected T-cell clone. Proc Natl Acad Sci USA 86:2365-2368.

65. Griffin GE, Leung K, Folks TM, Kunkel S, Nabel GJ (1989) Activation of HIV gene expression during monocyte differentiation by induction of NF-кB. Nature 339:70-73.

66. Bielinska A, Shivdasani RA, Zhang L, Nabel GJ (1990) Regulation of gene expression with double-stranded phosphorothioate oligonucleotides. Science 250:997-1000.

67. Gorman CM, Moffat LF, Howard BH (1982) Recombinant genomes which express chloramphenicol acetyl-transferase in mammalian cells. Mol Cell Biol 2:1044-1051.

68. Mosmann T (1983) Rapid colorimetric assay for cellular growth and survival: Application to proliferation and cytotoxicity assays. J Immunol Methods 65:55-63.

69. Setoyama C, Frunzio R, Liau G, Mudryj M, DeCrombrugghe $\mathrm{B}$ (1986) Transcriptional activation encoded by the $\mathrm{v}$-fos gene. Proc Natl Acad Sci USA 83:3213-3217.

70. Gunning P, Ponte P, Okayama H, Engel J, Blau H, Kedes L (1983) Isolation and characterization of full length cDNA clones for human $\alpha-, \beta$-, and $\gamma$-actin mRNAs: Skeletal but not cytoplasmic actins have an amino-terminal cysteine that is subsequently removed. Mol Cell Biol 3:787-795 